\title{
Tulburarea metabolică severă - cauză de deces la un sugar având o boală cronică
}

\author{
Roxana Tănase ${ }^{1}$, Alina Stoicescu ${ }^{2}$, Elena Georgescu ${ }^{1}$, \\ Carmen Pascu', Şerban Rogoz ${ }^{1}$, Oana Falup-Pecurariu ${ }^{1,3}$ \\ ${ }^{1}$ Spitalul de Urgenţă pentru Copii, Braşov, România \\ ${ }^{2}$ Spitalul MedLife, Braşov, România \\ ${ }^{3}$ Universitatea Transilvania, Braşov, România
}

\begin{abstract}
REZUMAT
Hiperplazia congenitală suprarenală reprezintă o tulburare în sinteza steroizilor, cu transmitere autozomal recesivă şi cu prevalenţă mare în cazul copiilor proveniţi din relaţii de consangvinitate.

Prezentăm cazul unui sugar de sex masculin, diagnosticat la vârsta de 2 luni cu sindrom de pierdere de sare şi hiperplazie congenitală suprarenală forma clasică fără semne de virilizare, alături de un review al datelor din literatura recentă legată de acest subiect. Diagnosticul a fost pus pe baza istoricului familial, a datelor clinice şi paraclinice. Prognosticul poate fi unul favorabil atât timp cât există complianţă la tratamentul de substituţie cu glucocorticoizi. Totodată, riscul de deces este ridicat prin crizele suprarenale şi dezechilibrul metabolic major.
\end{abstract}

Cuvinte cheie: hiperplazie congenitală suprarenală, glucocorticoizi, 21-hidroxilază, criză suprarenală

\section{INTRODUCERE}

Hiperplazia congenitală suprarenală (HCS) este o entitate care reuneşte un grup de deficiențe enzimatice cu trasmitere recesivă. Consecința majoră a acestei deficiențe constă în alterarea producției de steroizi la nivelul suprarenalei, determinând un deficit de cortizol şi aldosteron şi un exces de androgeni (1). Deficitul de 21-hidroxilază reprezintă cea mai frecventă anomalie, 95\% din totalul HCS regăsindu-se în această categorie (2).

Conform datelor recente din literatura de specialitate, HCS se clasifică astfel:

A. Forma clasică - hiperplazia congenitală a suprarenalelor

1. Deficitul de 21 hidroxilază
a) forma simplă virilizantă
b) forma cu pierdere de sare
c) forma criptică (latentă, atenuată)

2. Deficitul de 11 hidroxilază - forma cu hipertensiune arterială

3. Deficitul de 3 beta-hidroxisteroid-dehidrogenază

4. Deficitul altor enzime implicate în steroidogeneză.
B. Forma non-clasică (cu debut tardiv)

1. Forma cu virilizare şi infertilitate (deficit latent de 21 hidroxilază sau 3-beta-hidroxisteroid-dehidrogenază)

2. Forma cu virilizare şi hipertensiune arterială (deficit latent de 11-hidroxilază).

Tratamentul este mutidisciplinar, complex şi constă în: substituţia de steroizi, suplimentarea aportului de sare, evitarea crizelor suprarenale, corectarea chirurgicală a organelor genitale externe, precum şi menținerea unei sănătăți mentale corespunzătoare (1-3).

Se recomandă screeningul tuturor nou-născuților pentru deficitul sever de 21-hidroxilază. Testele pozitive necesită ulterior investigații pentru confirmarea diagnosticului $(3,4)$.

\section{PREZENTARE DE CAZ}

Sugar de sex masculin, în vârstă de 2 luni, se prezintă pentru refuzul alimentației şi agitație psihomotorie cu plâns neconsolabil. Simptomatologia a debutat cu o zi înaintea prezentării.

Din antecedentele heredocolaterale reținem că mama, în vârstă de 26 de ani (GIIIPIII), cu tatăl, în 
vârstă de 33 de ani, sunt verişori de gradul II. Au împreună încă 2 copii, un băiat în vârstă de 5 ani şi o fetiță în vârstă de 4 ani.

Cel de-al doilea copil, fetița, la vârsta de 6 săptămâni, s-a prezentat în serviciul nostru în şoc hipovolemic. Pe baza examenului clinic şi a investigaţiilor complementare, s-au stabilit diagnosticele de pseudohermafroditism de sex feminin, sindrom de pierdere de sare şi tulburare adrenogenitală. S-a efectuat inclusiv cariotiparea, care a confirmat deficitul de 21-hidroxilază. Tratamentul de substituție s-a făcut cu Prednison, Astonin (Fludrocortizon) şi suplimentarea aportului de sare, sub care evoluția a fost lent favorabilă.

Corecția chirurgicală a organelor genitale externe nu s-a efectuat până la vârsta de 4 ani, întrucât părinții au fost necomplianți față de programul de urmărire al acestui copil (Fig. 1).

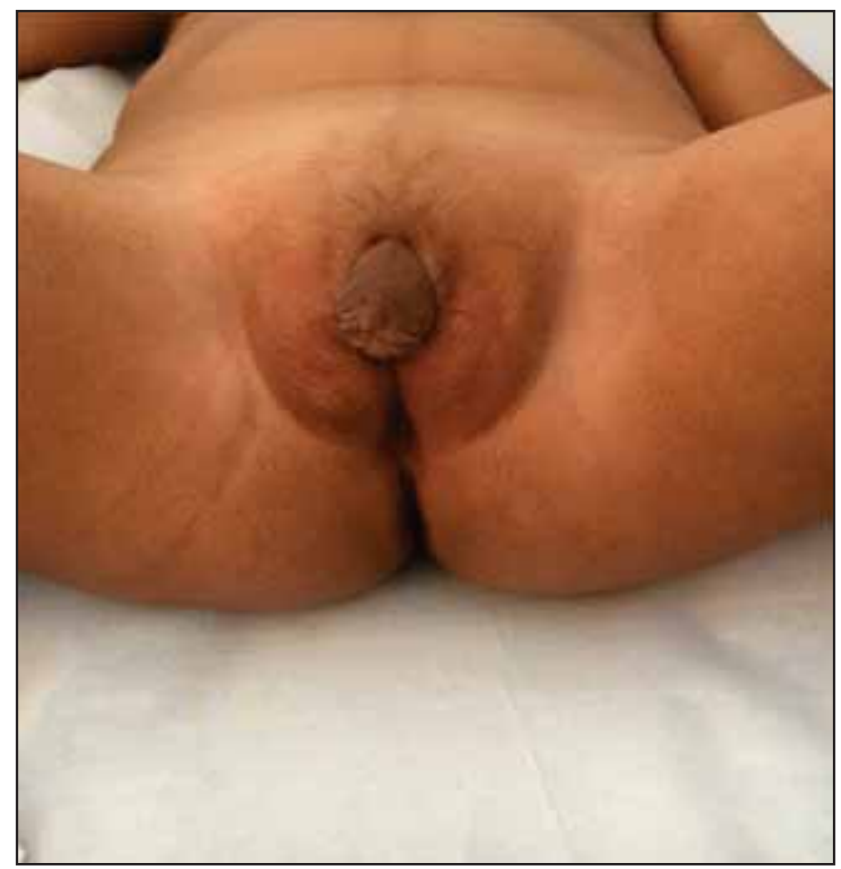

FIGURA 1. Fetiță în vârstă de 4 ani (sora pacientului nostru) - organe genitale externe cu aspect de psudohermafroditism feminin şi pilozitate pubiană.

Pacientul nostru, în vârstă de 2 luni, cel de-al treilea copil al familiei, provine dintr-o sarcină nedispensarizată, afirmativ cu evoluție fiziologică. Este născut la termen, pe cale naturală, în prezentație craniană, $\mathrm{GN}=3.900 \mathrm{~g}$, alimentat mixt, vaccinat BCG, profilaxia rahitismului neinițiată, curba ponderală descendentă.

La internare, prezintă stare generală mediocră, T $=37^{\circ} \mathrm{C}, \mathrm{G}=3.500 \mathrm{~g}$, facies suferind, încercănat, ochi înfundați în orbite, buze uscate, limbă saburală, plâns stins, tegumente palide, TRC $5 \mathrm{sec}$, extremități reci cu tendință la cianoză, torace normal conformat, murmur vezicular prezent bilateral, fără raluri, Sat O $298 \%$, AV 150 b/min, TA 90/60 mmHg, fără sufluri supraadăugate, abdomen suplu, depresibil, pliu cutanat cu elasticitate diminuată, turgor flasc, scaun semiconsistent, diureză prezentă, organe genitale externe de sex masculin dezvoltate corespunzător vârstei, ambii testiculi coborâți în scrot, FA 3/2 cm deprimată (Fig. 2).

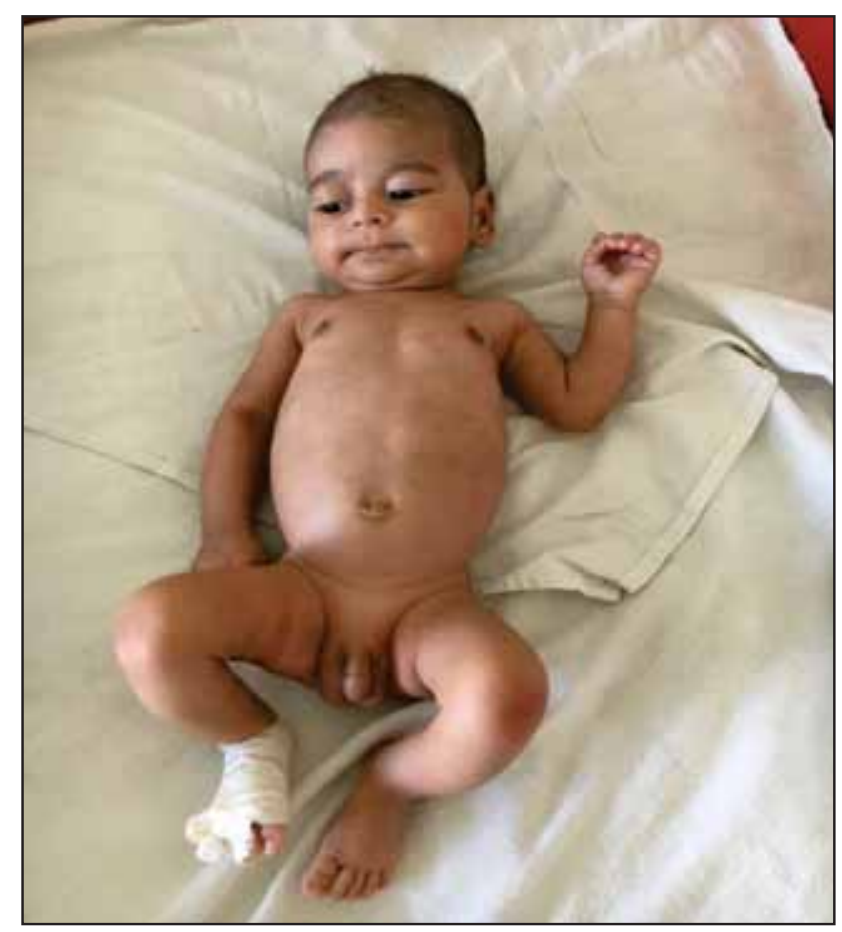

FIGURA 2. Pacientul nostru la vârsta de 2 luni. IP $=0,64$

Biologic, la prima internare, se evidențiază leucocite $15.880 / \mathrm{mmc}$, monocite $11,3 \%$, trombocite $690.000 / \mathrm{mmc}$, glicemia $69 \mathrm{v} \mathrm{mg/dl}, \mathrm{Na}=129$ $\mathrm{mmol} / 1$, calciu ionic $1,68 \mathrm{mmol} / 1$, uree $77,4 \mathrm{mg} / \mathrm{dl}$, potasiu $5,55 \mathrm{mmol} / 1$, acidoză metabolică, imunograma în limite normale, sumar de urină cu leucociturie, urocultura pozitivă cu E. coli, probele şi culturile din scaun negative, hemocultură negativă, Ig E specific la laptele de vacă - negativ.

Ecografic abdominal şi transfontanelar - fără imagini patologice.

S-a iniţiat tratament cu perfuzii de reechilibrare hidroelectrolitică şi de aport.

Având în vedere susceptibilitatea crescută la infecții a acestui sugar, s-a început antibioterapia empirică cu Ampicilină (100 mg/kg/zi), schimbată ulterior conform antibiogramei. Din cauza istoricului familial sugestiv pentru HCS şi a Na seric constant scăzut (124-129 mmol/1), se ia decizia lărgirii sferei investigațiilor cu efectuarea: TSH, FT4 (valori normale), 17-cetosteroizi/ urină $24 \mathrm{~h}(\mathrm{x} 2,5 \mathrm{VN} \uparrow), 17$ alfa hidroxiprogesteron, cortizol seric, renina plasmatică (x300VN $\uparrow)$, aldosteron (valori normale), 


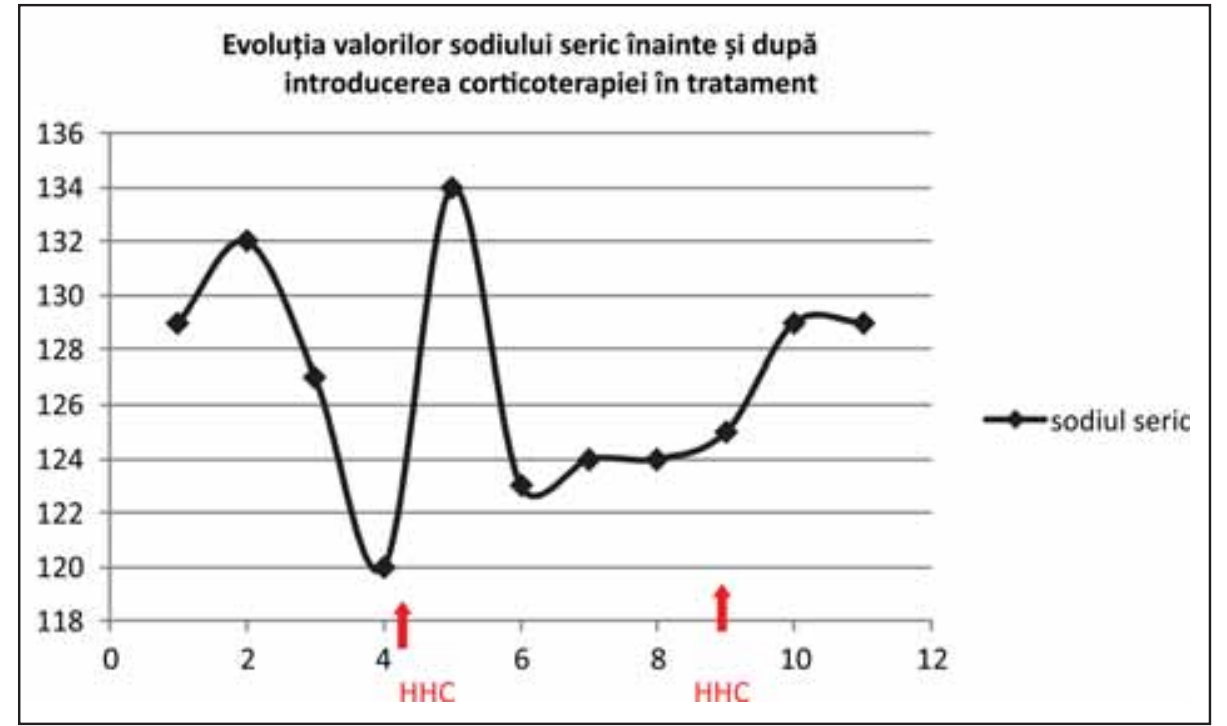

FIGURA 3. Dinamica valorilor sodiului seric pe parcursul internării sub tratamentul cu HHC. ionograma urinară, valorile pledând pentru diagnosticul de tulburare androgenitală cu sindrom de pierdere de sare. Conform recomandărilor endocrinologice, se adaugă la schema de tratament corticoterapia (hemisuccinat de hidrocortizon) (Fig. 3) şi suplimentarea aportului de sare, sub care evoluția devine favorabilă, cu revenirea apetitului şi curbă ponderală în creştere $(\mathrm{G}=3.720 \mathrm{~g}$ după 17 zile de tratament substitutiv).

Se efectuează consult genetic, care stabileşte diagnosticul antemenționat pe baza datelor familiale, clinice şi biologice. Geneticianul nu mai consideră necesară confirmarea mutației CYP21A2.

Sugarul este externat la domiciliu cu tratament de substituţie cu Prednison 2,5 mg/zi po şi aport suplimentar de sare în alimentație. Revine în serviciul nostru după 3 zile, în şoc hipovolemic, acidoză metabolică severă, hiponatremie severă $(\mathrm{Na}=123$ mmol/l) şi refuzul alimentației. Se iniţiază terapia de substituție, însă valorile sodiului se mențin mici şi apar tulburări de ritm cardiac. În acest moment, se iniţiază administrarea de sodiu continuă, însă pacientul decedează prin tulburare de rim cardiac.

Anatomopatologic, dimensiunile şi greutatea glandelor suprarenale se află peste valoarea normală corespunzătoare taliei pacientului $(8,3$ grame față de 5 grame). Microscopic, s-a decelat arhitectură dezorganizată atât a zonei corticale, cât şi a celei medulare.

\section{DISCUTुII}

Hiperplazia congenitală suprarenală reprezintă o tulburare în biosinteza suprarenală de steroizi. Unele forme autozomal recesive afectează şi steroidogeneza gonadală. 21-hidroxilaza, enzima ce ca- talizează conversia 17-hidroxiprogesteronului în 11-deoxicortizol, este cel mai frecvent deficitară în cadrul acestei patologii (5).

Mutația sau deleția oricărei gene care codifică enzimele implicate în sinteza cortizolului sau aldosteronului determină hiperplazia congenitală suprarenală. Fenotipul particular ce rezultă în urma acestor mutații depinde de sexul individului, locul unde este blocată sinteza şi de severitatea deleției sau mutaţiei (5).

Incidența globală a acestei boli a fost estimată la 1:14.199 naşteri vii la pacienții homozigoți şi 1:60 la subiecții heterozigoți, cu o frecvență a genei de 0,0083. Incidența HCS în cadrul populației de culoare albă a fost estimată la 1:11.909 pentru pacienții homozigoți şi 1:55 pentru subiecții heterozigoți, cu o frecvență a genei de 0,0091. Incidența formei de HCS cu pierdere de sare a fost stabilită la 1 : 18.850 , comparativ cu forma simplă virtilizantă 1 : 57.543; astfel, forma cu pierdere de sare este de 3 ori mai comună decât forma simplă virilizantă.

O prevalență înaltă a bolii a fost descrisă în Tunisia, la evrei şi în estul Europei, acolo unde a fost declarată cea mai mare rată de consangvinitate. Peste jumătate dintre pacienți sunt copii proveniţi din relații de consangvinitate (6). Consangvinitatea se constată şi în cazul pacientului nostru.

Conform protocolului clinic al Societăţii Americane de Endocrinologie, se recomandă screeningul tuturor nou-născuților pentru deficitul sever de 21-hidroxilază, iar rezultatele pozitive trebuie urmate de teste de confirmare $(3,4)$. Validitatea screening-ului este controversată, deoarece nivelele de 17-hidroxiprogesteron variază cu vârsta gestaţională, iar acuratețea testului poate fi compromisă de reacții încrucişate cu alți corticosteroizi. 
La prematuri există o rată mare de teste fals pozitive, astfel încât nu este necesar screeningul lor în masă. Prematurii reprezintă o categorie de pacienți care trebuie atent monitorizați şi spitalizați pe perioade îndelungate. Orice manifestare a sindromului de pierdere de sare sau criză suprarenală este imediat observată şi tratată prompt în cadrul acestei categorii particulare de pacienți $(7,8)$.

Cariotiparea trebuie efectuată doar în cazurile în care diagnosticul este echivoc sau în cazurile în care se doreşte consiliere genetică, după cum s-a constatat şi în cazul nostru. Datele familiale, clinice şi paraclinice (hormonale) sunt principalele elemente pentru diagnostic (3).

Clinic, în formele clasice, se descrie sindromul de pierdere de sare, care poate merge până la crize suprarenale amenințătoare de viață, prin imposibilitatea menținerii balanței sodiului, virilizarea organelor genitale feminine (hipertrofie clitoridiană, fuziune labială), falimentul creşterii. Aceste simptome apar devreme, obişnuit sub vârsta de 1 an $(1,9)$. Formele non clasice sau cu debut tardiv, cu o medie a vârstei de 5,9 ani, implică pubarhă precoce, maturarea prematură a epifizelor, accelerarea creşterii şi o statură mică în perioada de adult, cicluri menstruale neregulate, infertilitate posibilă la ambele sexe $(1,9)$, tumori testiculare din resturi de țesut suprarenal, oligospermie (10). Pacientul nostru se încadrează în forma clasică de boală cu pierdere de sare, fără semne de virilizare şi exitus prin tulburare metabolică severă.

Tratamentul clasic constă în înlocuirea cortizolului şi aldosteronului deficitar şi în gestionarea simptomelor determinate de excesul în androgeni, utilizând cea mai mică doză de glucocorticoid posibilă, pentru evitarea efectelor adeverse, în principal a sindromul Cushing iatrogen $(2,4)$. Hidrocortizonul este citat ca medicaţie de primă intenție (5). Şi în cazul nostru, corticoterapia s-a iniţiat cu hemisuccinat de hidrocortizon. Aportul de sare a fost suplimentat per os, conform recomandărilor din literatură, 2-4 g/zi (4).

Atunci când diagnosticul este stabilit antenatal prin teste genetice, se ia în considerare tratamentul cu dexametazonă şi are ca scop prevenirea virilizării feților de sex feminin.

În perioada pubertății, metabolismul cortizolului se modifică, cu o creştere a clearance-ului, necesitând ajustarea în permanenţă a dozelor, în sensul creşterii lor. Ca variantă terapeutică, se poate administra hidrocortizonul subcutan, folosind o tehinică asemănătoare pompelor de insulină (5).

Pentru fetițele cu virilizare severă, ar trebui luată în considerare chirurgia reparatorie într-un sin- gur pas operator, efectuată de chirurgi experimentați în acest domeniu (3).

În cazul formelor non-clasice, tratamentul trebuie adaptat conform simptomelor, ținta acestuia fiind o curbă a creşterii liniară, maturare osoasă normală, pubertate la timp, cicluri menstruale regulate, prevenția sau limitarea progresiei hirsutismului şi acneei. Tratamentul trebuie individualizat şi nu trebuie iniţiat pentru scăderea concentrației crescute de hormoni (13).

Ca orice boală cronică, impactul bolii şi al tratamentului substitutiv pentru toată viața predispune la o izolare socială a acestor pacienți. De aceea, colaborarea multi- şi interdisciplinară dintre pediatri, endocrinologi, chirurgi, psihologi şi geneticieni este vitală pentru creşterea calității vieții acestora. În afara faptului că tratamentul este zilnic, pacienţii cu hiperplazie congenitală suprarenală pot avea o viață normală.

Factorii care pot afecta calitatea vieții la pacienții cu HCS includ medicația pentru toată viața, riscul de criză suprarenală şi simptomele hiperandrogenice (12).

La pacienții cu HCS s-a constatat că au rezultate şcolare mai scăzute, iar pe plan social reuşesc cu dificultate să obțină relații de prietenie cu colegii (12).

În foarte multe cazuri, a fost raportată necomplianța la tratament, expunând pacienții la crize suprarenale. Acest lucru a fost dovedit şi în cazul nostru: sora pacientului a prezentat internări multiple pentru dezechilibru hidroelectrolitic şi sindrom de deshidratare, iar intervenția chirurgicală nu a avut loc până la vârsta de 4 ani prin neprezentare în serviciul de chirurgie conform recomandărilor. Pacientul nostru revine de la domiciliu, după 3 zile, cu stare generală alterată, hiponatremie severă şi deshidratare acută.

Schemele de tratament subtitutiv sunt complexe şi necesită administrarea medicaţiei în anumite momente ale zilei pentru a mima ritmul fiziologic al cortizolului în organism. Educaţia este un element de bază, iar pacienții învață cum să îşi ajusteze dozele ca răspuns la efort, stres psihologic sau boli minore.

Există necomplianţă la dozele stabilite de medici, cât şi noncomplianţă la intervalele de administrare (13).

\section{CONCLUZII}

Consangvinitatea reprezintă un factor de risc important în apariția HCS. În cazul de față, există doi copii afectați, de sexe diferite, la care evoluția 
bolii a fost diferită. Ambii prezintă forma clasică a bolii, prin deficit de 21-hidroxilază cu sindrom de pierdere de sare, diagnosticată devreme, la vârsta de 6 săptămâni, respectiv 2 luni. Tratamentul substitutiv cu glucocorticoizi şi aportul suplimentar de sare per os s-a instituit ambilor pacienți, cu evoluție favorabilă în cazul fetiței, cu menținerea unui echilibru metabolic şi hormonal, şi nefavorabilă în cazul fratelui său, care decedează prin criză suprarenală.

\section{MULȚUMIRI}

Părinții au înțeles aspectele acestei patologii, li s-au explicat toate informațiile pe înțelesul lor şi au fost de acord cu utilizarea dosarelor medicale, inclusiv efectuarea de poze strict în scop ştiinţific şi didactic. Pentru acest lucru, întreaga echipă le mulțumeşte. 